medRxiv preprint doi: https://doi.org/10.1101/2021.05.18.21252341; this version posted May 20, 2021. The copyright holder for this preprint (which was not certified by peer review) is the author/funder, who has granted medRxiv a license to display the preprint in perpetuity.

It is made available under a CC-BY 4.0 International license .

A model framework for projecting the prevalence and impact of Long-COVID in the UKA model framework for projecting the prevalence and impact of Long-COVID in the UK

\title{
1 A model framework for projecting the prevalence and impact of Long-COVID s in the UK
}

Chris Martin, Director of Modelling, Crystallise. Honorary Researcher, UCL Institute of Health

Informatics.

Michiel Luteijn, Biometric Research Data Specialist at Hannover Re UK Life branch. 10 Fenchurch

William Letton, Research and Development Consultant, Crystallise. 
medRxiv preprint doi: https://doi.org/10.1101/2021.05.18.21252341; this version posted May 20, 2021. The copyright holder for this preprint (which was not certified by peer review) is the author/funder, who has granted medRxiv a license to display the preprint in perpetuity.

It is made available under a CC-BY 4.0 International license .

A model framework for projecting the prevalence and impact of Long-COVID in the UKA model framework for projecting the prevalence and impact of Long-COVID in the UK

Keyword list

Long-COVID, SARS-CoV-2, COVID-19, EQ-5D, Quality Adjusted Life Years

Abstract

\section{Background}

The objective of this paper is to model lost Quality Adjusted Life Years (QALYs) from symptoms arising from COVID-19 in the UK population, including symptoms of 'long-COVID'. The scope includes QALYs lost to symptoms, but not deaths, due to acute COVID-19 and long COVID.

\section{Methods}

The prevalence of symptomatic COVID-19, encompassing acute symptoms and long-COVID symptoms, was modelled using a decay function. Permanent injury as a result of COVID-19 infection, was modelled as a fixed prevalence. Both parts are combined to calculate QALY loss due to COVID-19 symptoms.

\section{Results}

Assuming a $60 \%$ final attack rate for SARS-CoV-2 infection in the population, we modelled 299,719 QALYs lost within 1 year of infection (90\% due to symptomatic COVID-19 and 10\% permanent injury) and 557,754 QALYs lost within 10 years of infection (49\% due to symptomatic COVID-19 and 51\% due to permanent injury). The UK Government willingness-to-pay to avoid these QALY losses would be $£ 17.9$ billion and $£ 32.2$ billion, respectively. Additionally, 90,143 people were subject to permanent injury from COVID-19 (0.14\% of the population).

\section{Conclusion}

Given the ongoing development in information in this area, we present a model framework for calculating the health economic impacts of symptoms following SARS-CoV-2 infection. This model framework can aid in quantifying the adverse health impact of COVID-19, long COVID and permanent injury following COVID-19 in society and assist the proactive management of risk posed to health. Further research is needed using standardised measures of patient reported outcomes relevant to long COVID and applied at a population level. 
medRxiv preprint doi: https://doi.org/10.1101/2021.05.18.21252341; this version posted May 20, 2021. The copyright holder for this preprint (which was not certified by peer review) is the author/funder, who has granted medRxiv a license to display the preprint in perpetuity.

It is made available under a CC-BY 4.0 International license.

A model framework for projecting the prevalence and impact of Long-COVID in the UKA model framework for projecting the prevalence and impact of Long-COVID in the UK

\section{Introduction}

In December 2019, a series of pneumonia cases, now known to be caused by the novel SARS-Cov-2 virus, emerged in Wuhan, China (1). The novel SARS-Cov-2 virus quickly spread across the globe and on March $11^{\text {th }}, 2020$, the WHO made the assessment that COVID-19 can be characterised as a pandemic. As of April 2021, the global confirmed death toll stands at over 1.4 million, with over 150,000 deaths mentioning COVID-19 on the death certificate in the UK $(2,3)$.

Over the course of the COVID-19 pandemic, it has emerged that some COVID-19 patients suffer symptoms long after initial infection. The National Institute for Health and Care Excellence (NICE) has defined three phases to symptoms following COVID-19 (4). First, 'Acute COVID-19 infection' covers the period of active infection up to 4-weeks post-infection. Second, 'Ongoing symptomatic COVID-19' covers the period when infection should have ceased but persisting effects from the infection that may take time to heal may be present from 4 and 12-weeks post-infection. Third, 'Post-COVID-19 syndrome' is defined as 'Signs and symptoms that develop during or following an infection consistent with COVID-19, continue for more than 12 weeks and are not explained by an alternative diagnosis.' Long COVID describes both ongoing symptomatic COVID-19 as well as post-COVID-19 syndrome. Documented symptoms for long COVID include breathlessness, fatigue, myalgia, chest pains and insomnia (5).

Post-COVID-19 syndrome may persist long after active infection has ceased and in some cases symptoms will be permanent. Lung scarring following coronavirus related ARDS or from the highpressure mechanical ventilation used in its treatment has been widely documented (6). In a study of patients with acute respiratory distress syndrome about a third of those who were previously employed were still unemployed 5-years later (7), suggesting long term disability. A dysfunctional and uncontrolled immune response can cause multi-organ damage, particularly the liver and kidneys, and disrupt the coagulation control mechanisms of the blood (8). This can precipitate major adverse cardiovascular events which may have long-term consequences such as heart failure or hemiplegia. Data from the COVID Infection Survey study on long-COVID suggests that the risk of major adverse cardiovascular events is about ten times higher in cases with non-intensive care hospitalized patients with COVID when compared to matched controls (9). Following treatment in critical care with acute respiratory distress syndrome, about $25 \%$ of patients have post-traumatic stress disorder and about $40 \%$ suffer depression $(10,11)$. Severe illness often results in prolonged periods of immobility which range from simple lack of exercise to prolonged bed rest, resulting in further knock-on health impacts. Severe acute respiratory syndrome (SARS) and Middle East respiratory syndrome (MERS) are examples of two other coronavirus outbreaks that have caused similar symptoms to SARS-Cov-2 in the acute stage of infections (i.e., viral pneumonia and ARDS). A recent systematic review and meta-analysis that evaluated the long-term clinical outcomes after SARS and MERS suggest similar symptoms were found 6 to 12-months post discharge, namely reduced lung function, reduced ability to exercise, PTSD, depression, anxiety and reduced Quality of Life scores (12).

The objective of this paper is to model lost Quality Adjusted Life Years (QALYs) from both acute COVID19 and long COVID symptoms arising from COVID-19 in the UK population. The scope does not include COVID-19 deaths. The parameterisation of the model was based on a literature review. This modelling framework divides the symptomatic cohort into two groups: symptomatic COVID and COVID (permanently) injured. The symptomatic COVID group includes all three NICE defined categories described earlier. The assumption is that there are a variety of patterns of illness in the survivors with varying duration and differing aetiologies, but that all are self-limiting and will eventually recover. The COVID injured group includes people in the post-COVID-19 syndrome group that may have persisting 
medRxiv preprint doi: https://doi.org/10.1101/2021.05.18.21252341; this version posted May 20, 2021. The copyright holder for this preprint (which was not certified by peer review) is the author/funder, who has granted medRxiv a license to display the preprint in perpetuity.

It is made available under a CC-BY 4.0 International license .

A model framework for projecting the prevalence and impact of Long-COVID in the UKA model framework for projecting the prevalence and impact of Long-COVID in the UK

symptoms as a result of permanent injury following infection and associated treatment. These symptoms are assumed to be permanent for the purpose of modelling.

\section{Method}

\section{Model}

We modelled QALYs lost due to COVID-19 illness, but not deaths, in the UK population of 66.6 million. Our baseline model assumed a $60 \%$ attack rate at day 0 and no reinfections. Univariate sensitivity analysis was carried out on key model parameters. Symptom prevalence for the SARS-Cov-2 infected is modelled using a decay function based on the national Coronavirus Infection Survey (9). A second group, the COVID permanently injured, is kept at a fixed prevalence. Both symptomatic COVID-19 cases and the permanently injured were divided into three mutually exclusive treatment groups: nonhospitalised, ward-based care and ITU care (Figure 1). For the symptomatic COVID-19 cases, COVID19-related QALY loss differed by treatment group, while the probabilities of emerging with permanent injury also vary by treatment group.

The core of the model is a calculation of the cumulative days lived with symptoms and/or permanent injury up to the modelled time-horizon, multiplied by the number of Quality Adjusted Life Years lost per day for those with symptoms and discounted over time. The time horizon is set at the life expectancy for both the Symptomatic COVID and COVID injured cohorts. Taking account of the age distribution of people admitted with COVID-19 (13), the population weighted average life expectancy for them as of 2019 is 19.19 years (own calculations). It is expected that those admitted are in poorer health than the population average and so a reduction factor of $50 \%$ is applied to reach a time horizon of 10 years for hospitalised patients. This is in-line with Briggs et al, who estimate the life expectancy of the average UK COVID-19 death at 10.94 years (14). Model parameters, plus their sources, are summarised in Table 1.

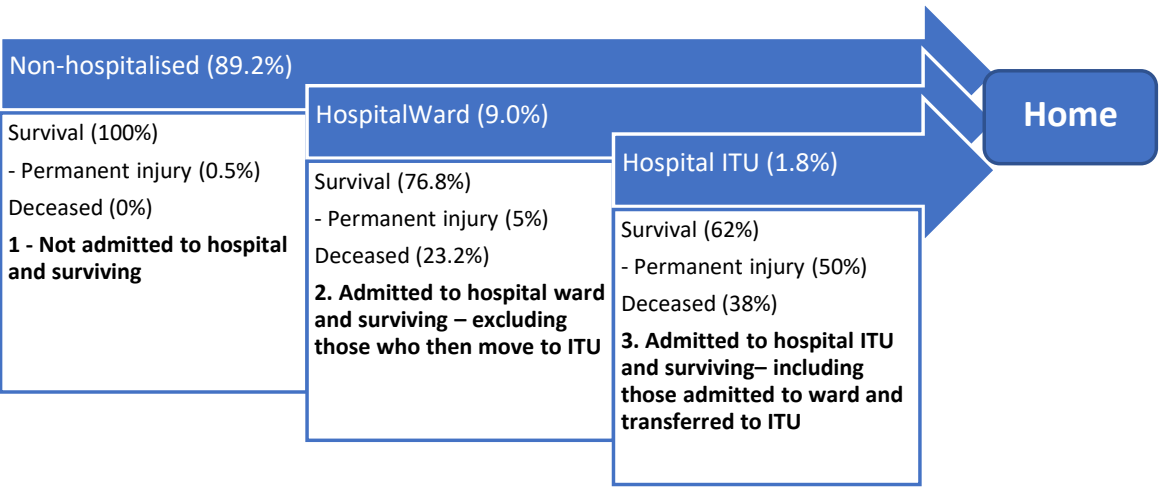

Figure 1. The pathways of care for the three survivor compartments amongst symptomatic patients.

\section{Model parameters}

\section{Prevalence of symptoms}

UK surveys of prevalence of symptoms show a range of outcomes, with hospital-based surveys $(5,15)$ showing higher and an app-based survey (16) showing a lower prevalence of symptoms than the national Coronavirus Infection Survey (9) (Figure 2). The national Coronavirus Infection Survey is considered most relevant as it contains the largest sample and provides a reference to the UK general population prevalence. The Coronavirus Infection Survey consists of a random, a-priori, selected sample that is invited for COVID tests and therefore would cover asymptomatic and symptomatic 
medRxiv preprint doi: https://doi.org/10.1101/2021.05.18.21252341; this version posted May 20, 2021. The copyright holder for this preprint (which was not certified by peer review) is the author/funder, who has granted medRxiv a license to display the preprint in perpetuity.

It is made available under a CC-BY 4.0 International license .

A model framework for projecting the prevalence and impact of Long-COVID in the UKA model framework for projecting the prevalence and impact of Long-COVID in the UK

cases. Two key data points provide the prevalence of symptoms at 5 and 12 -weeks, which were approximately $20 \%$ and $10 \%$ respectively. A natural history of symptom prevalence over time was fitted to all infections in the model by fitting an exponential decay curve on these two data points, plus a $50 \%$ symptom prevalence assumed at $t=0$ (Equation 1 ).

Equation 1

Where:

$$
P_{\text {Symptomatic COVID }, t}=0.4548 * e^{-0.132 * t}
$$

- $P_{t}$ is the prevalence of any symptoms at time $t$ in weeks following infection.

- Decay function constant $=0.4548$ and rate of decay $=-0.132$ derived using CIS study data points.

Figure 2: Symptom prevalence across studies identified in the UK by duration and severity group.

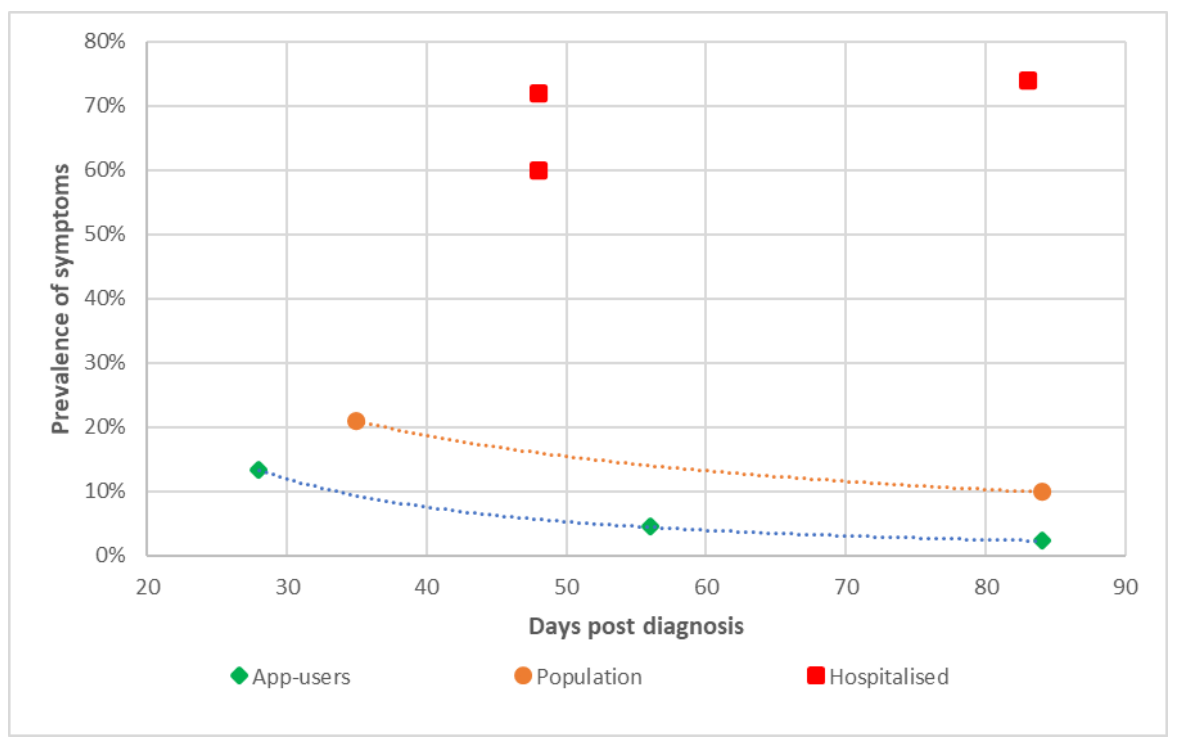

\section{Distribution of groups and group mortality outcomes}

The number of UK positive tests $(2,657,305)$ and hospital admissions $(287,662)$ with COVID-19 up to $31^{\text {st }}$ October 2020 indicates $10.8 \%$ of known cases were admitted to hospital (3). We assume a similar distribution for symptomatic cases. Assuming the mortality rate in the non-hospitalised group is negligible, the surviving non-hospitalised fraction of all positive tests is $89.2 \%$. Of those admitted to hospital (10.8\%), $16.5 \%$ of these are admitted to critical care (17) leaving $9.0 \%$ of all cases who are admitted for ward-care only. The mortality rate for critical care patients was 38\% in October 2020 (18) meaning $62 \%$ of the $1.8 \%$ of cases admitted to critical care survive (1.1\%). As of the $31^{\text {st }}$ August 2020 there had been 118,613 patients admitted to hospital in England, Wales and Northern Ireland (excluding ITU). Of those, 27,483 died on the wards making the ward mortality $23.2 \%$ with $76.8 \%$ surviving $(3,19)$. Therefore, $6.9 \%$ of the $9.0 \%$ admitted for ward-care survive.

\section{Prevalence of permanently injured}

The proportion of known COVID-19 cases that are permanently injured is not yet known. It is assumed that only patients with positive COVID-19 tests that had symptoms at 6 weeks post-COVID infection can get permanent injury. Based on an estimated $12 \%$ of the 66.6 million UK population having been infected (20) and 2.66 million positive COVID-19 tests (3) as of December 31 $1^{\text {st }}, 2020,33 \%$ of SARS-Cov- 
medRxiv preprint doi: https://doi.org/10.1101/2021.05.18.21252341; this version posted May 20, 2021. The copyright holder for this preprint (which was not certified by peer review) is the author/funder, who has granted medRxiv a license to display the preprint in perpetuity.

It is made available under a CC-BY 4.0 International license .

A model framework for projecting the prevalence and impact of Long-COVID in the UKA model framework for projecting the prevalence and impact of Long-COVID in the UK

152

153

154

155

156

157

158

159

160

161

162

163

164

165

166

167

168

169

170

171

172

173

174

175

176

177

178

179

180

181

182 set at $72 \%$ for ITU and $60 \%$ for ward patients (15), while for non-hospitalised patients it is set at $16 \%$ (interpolated from the COVID Infection survey (9)).

About a third of previously employed patients with ARDS were still unemployed 5-years later (7). We assume that disability arising from the illness was the sole cause of unemployment and that a fraction who are injured may manage to return to work, implying an injured figure higher than $33 \%$. Reflecting this uplift, we estimate that $50 \%$ of the ITU survivors with symptoms at 6 weeks post-COVID will be left permanently injured. For the ward-based group and the non-hospitalised group, we assume $5 \%$ permanently injured and $0.5 \%$ permanently injured amongst survivors symptomatic at 6 weeks postCOVID, respectively ( $10 \%$ and $1 \%$ of the ITU rate, respectively). Using the breakdown between nonhospitalised (89.2\%), ward (9\%) and ITU (1.8\%) populations for symptomatic cases, taking into account deaths in the latter two groups, results in a weighted prevalence of $0.62 \%$ permanently injured amongst COVID-19 cases with positive tests. Adjusting for positive tests only results in a final $0.2 \%$ prevalence of the permanently injured amongst all COVID-19 cases.

Utility

Average loss of utility for hospitalised COVID-19 patients, split by general ward-care (-6.1\%), and care on ITU treatment (-15.5\%) was reported in the UK after a mean of 48 days (15). For the purpose of the model, we take the prevalence of persisting symptoms as that of the prevalence of persistent fatigue (72\% for ITU patients and $60 \%$ for ward-only patients) on the assumption that the vast majority of other symptoms will co-exist with fatigue. The reported average utility change is converted into the COVID-19 symptomatic utility change using the persisting symptom prevalence. This results in a COVID-19 symptomatic utility change of $-6.1 \% / 60 \%=-10 \%$ for ward patients and $-15.5 \% / 72 \%=-22 \%$ for ITU patients symptomatic at 48 days post COVID-19. It was not possible to source utility for a UK non-hospitalised population. We assumed the utility loss for non-hospitalised COVID-19 patients with persistent symptoms to be the same as for the ward-based patients at $-10 \%$.

The utility for the permanently injured group is taken from a secondary health-economic analysis of a randomised controlled trial of 795 patients ventilated in critical care in the UK (21). At one-year postdischarge, mean utility was 0.58 , both for those above and below the age of 65 . Taking into account the reference population utility for the UK (0.856) (22), the ARDS specific utility at 1-year is calculated at $0.58 / 0.856=0.68$.

Aggregate COVID-specific utility for the symptomatic COVID cohort was calculated at $-11 \%$, using a weighted sum of the utilities for the three treatment groups (ward, ITU and population). 
medRxiv preprint doi: https://doi.org/10.1101/2021.05.18.21252341; this version posted May 20, 2021. The copyright holder for this preprint (which was not certified by peer review) is the author/funder, who has granted medRxiv a license to display the preprint in perpetuity.

It is made available under a CC-BY 4.0 International license .

A model framework for projecting the prevalence and impact of Long-COVID in the UKA model framework for projecting the prevalence and impact of Long-COVID in the UK

Table 1: Key parameter values used in this analysis.

\begin{tabular}{|c|c|c|c|c|}
\hline Parameter & Value & Source & Evidence strength & $\begin{array}{l}\text { Sensitivity } \\
\text { analysis }\end{array}$ \\
\hline Infection attack rate & $60 \%$ & $\begin{array}{l}\text { Results of an age-stratified, susceptible, exposed, } \\
\text { infected, recovered and died (SEIRD) model (own } \\
\text { calculations). }\end{array}$ & $\begin{array}{l}\text { key assumption update as risk } \\
\text { of infection varies. Availability } \\
\text { of testing may impact figures. }\end{array}$ & $48-72 \%$ \\
\hline $\begin{array}{l}\text { Prevalence function for } \\
\text { prevalence of symptoms } \\
\text { post COVID-19 by the } \\
\text { day. }\end{array}$ & $\begin{array}{l}P_{S} \\
=C \cdot e^{-\lambda . d a y s} \\
C=0.4548 \\
I=0.132\end{array}$ & $\begin{array}{l}\text { Fitted to the results of the CIS long-COVID report } \\
\text { December } 2020 \text { (9) plus an assumed 50\% } \\
\text { symptoms at } t=0 .\end{array}$ & $\begin{array}{l}\text { key assumption update as } \\
\text { evidence emerges }\end{array}$ & $\begin{array}{l}\text { Constant } \\
\text { term } 0.3638- \\
0.5458\end{array}$ \\
\hline $\begin{array}{l}\text { Prevalence of symptoms } \\
\text { at } 6 \text {-weeks for survivors } \\
\text { of ITU. }\end{array}$ & $72 \%$ & (15) & & \\
\hline $\begin{array}{l}\text { Prevalence of symptoms } \\
\text { at } 6 \text {-weeks in ward-care } \\
\text { only survivors. }\end{array}$ & $60 \%$ & (15) & & \\
\hline $\begin{array}{l}\text { Proportion of ITU } \\
\text { survivors with persistent } \\
\text { symptoms at } 6 \text {-weeks } \\
\text { who are permanently } \\
\text { injured. }\end{array}$ & $50 \%$ & $\begin{array}{l}\text { An assumption based on the observation that } 33 \% \\
\text { of those employed at the time of admission to ITU } \\
\text { with ARDS are still unemployed 5-years later ( } 7 \text { ) } \\
\text { with an up-lift applied to reflect those returning to } \\
\text { work while permanently injured. }\end{array}$ & $\begin{array}{l}\text { Placeholder estimate to be } \\
\text { updated when evidence } \\
\text { emerges }\end{array}$ & $40-60 \%$ \\
\hline $\begin{array}{l}\text { Proportion of ward-care } \\
\text { survivors with persistent } \\
\text { symptoms at } 6 \text {-weeks } \\
\text { who are permanently } \\
\text { injured. }\end{array}$ & $5 \%$ & $\begin{array}{l}\text { An assumption that the prevalence is } 10 \% \text { of the } \\
\text { ITU prevalence. }\end{array}$ & & \\
\hline $\begin{array}{l}\text { Proportion of non- } \\
\text { hospitalised cases with } \\
\text { persistent symptoms at } \\
\text { 6-weeks who are } \\
\text { permanently injured. }\end{array}$ & $0.5 \%$ & $\begin{array}{l}\text { An assumption that the prevalence is } 10 \% \text { of the } \\
\text { ward-care prevalence. }\end{array}$ & & \\
\hline $\begin{array}{l}\text { Proportion of all known } \\
\text { cases surviving critical } \\
\text { care. }\end{array}$ & $1.1 \%$ & $\begin{array}{l}\text { Calculated from the proportion of cases admitted } \\
\text { to ITU and the survival rate on ITU. }\end{array}$ & $\begin{array}{l}\text { Survival and hospitalisation } \\
\text { rates may change as } \\
\text { treatment improves, vaccine }\end{array}$ & \\
\hline $\begin{array}{l}\text { Proportion of all known } \\
\text { cases surviving ward. }\end{array}$ & $6.9 \%$ & $\begin{array}{l}\text { Calculated from the proportion of cases admitted } \\
\text { to a hospital ward and the survival rate on the } \\
\text { ward. }\end{array}$ & $\begin{array}{l}\text { reduce disease risk, virus } \\
\text { variants impact fatality. }\end{array}$ & \\
\hline $\begin{array}{l}\text { Proportion of all known } \\
\text { cases that are non- } \\
\text { hospitalised that survive. }\end{array}$ & $89.2 \%$ & $\begin{array}{l}\text { The proportion of cases not admitted on the } \\
\text { assumption that the mortality rate is negligible in } \\
\text { this group. }\end{array}$ & & \\
\hline $\begin{array}{l}\text { Adjusted prevalence of } \\
\text { permanent injury for all } \\
\text { infections, known and } \\
\text { unknown. }\end{array}$ & $0.226 \%$ & $\begin{array}{l}\text { Calculated from the prevalence of permanent } \\
\text { injury in known cases and the proportion of all } \\
\text { infections that are identified as cases. }\end{array}$ & $\begin{array}{l}\text { key assumption update as } \\
\text { evidence emerges }\end{array}$ & $0.182-0.273$ \\
\hline $\begin{array}{l}\text { Utility loss for all } \\
\text { symptomatic cases }\end{array}$ & 0.103 & $\begin{array}{l}\text { Derived from weighting the average utility loss for } \\
\text { symptomatic ward and ITU survivors at } 6 \text { weeks } \\
\text { (15). Symptomatic non-hospitalised patients are } \\
\text { assumed to have similar utility loss as symptomatic } \\
\text { ward patients. }\end{array}$ & & $0.082-0.123$ \\
\hline $\begin{array}{l}\text { Utility loss for those left } \\
\text { with permanent injury } \\
\text { post-COVID. }\end{array}$ & 0.318 & $\begin{array}{l}\text { Calculated from the utility loss at 1-year post ITU } \\
\text { discharge for ARDS ( } 21 \text { ) and the population norm } \\
\text { for England ( } 22) \text {. }\end{array}$ & $\begin{array}{l}\text { Evidence will need to be } \\
\text { accumulated for COVID-19 }\end{array}$ & $0.254-0.381$ \\
\hline Time horizon (years) & 10 & $\begin{array}{l}\text { Assumption based on adjusted weighted } \\
\text { population life expectancy for COVID-19 hospital } \\
\text { admissions. }\end{array}$ & $\begin{array}{l}\text { Key assumption update as } \\
\text { evidence emerges. }\end{array}$ & $1-20$ \\
\hline $\begin{array}{l}\text { Annual discount rate for } \\
\text { future QALYs }\end{array}$ & $1.5 \%$ & (23) & & \\
\hline $\begin{array}{l}\text { Monetary value per } \\
\text { QALY }\end{array}$ & $f 60,000$ & (23) & & \\
\hline
\end{tabular}


medRxiv preprint doi: https://doi.org/10.1101/2021.05.18.21252341; this version posted May 20, 2021. The copyright holder for this preprint (which was not certified by peer review) is the author/funder, who has granted medRxiv a license to display the preprint in perpetuity.

It is made available under a CC-BY 4.0 International license .

A model framework for projecting the prevalence and impact of Long-COVID in the UKA model framework for projecting the prevalence and impact of Long-COVID in the UK

\section{Results}

We modelled QALY loss due to COVID-19 symptoms, but not deaths. Within a 1-year time-horizon, the estimated undiscounted QALY loss in survivors was $299,719(0.6 \%$ of the total expected QALYs for that year) with 271,027 QALYs (92\%) lost to symptomatic COVID-19 in the acute, ongoing and post-COVID syndrome; and 28,692 (8\%) lost to permanent injury from COVID-19 including lung fibrosis, the sequelae of major adverse cardiovascular events like heart attacks and strokes and psychological impacts such as PTSD. Discounted QALY loss was 298,932, representing a monetary value of $£ 17.9$ billion based on the UK Governments willingness-to-pay per QALY (23), and a loss of about 0.0075 QALY per infection. With a 10-year time-horizon, the estimated total undiscounted QALY loss in survivors was 557,754 with 271,300 (54\%) QALYs lost to symptomatic COVID-19 in the acute, ongoing and post-COVID syndrome, 286,454 (46\%) lost to permanent injury from COVID-19. Discounted QALY loss was 536,867 , representing a monetary value of $£ 32.2$ billion and a loss of about 0.013 QALY per infection. Regardless of timeframe, an estimated 90,142 people would be left with permanent injury.

Following infection, QALY-loss due to symptomatic COVID-19 increases with time, but quickly levels off as people recover. However, for those living with permanent damage, QALY-loss accumulates over their life expectancy (Figure 3).

Figure 3. Cumulative QALY loss for symptomatic COVID and permanent injury due to COVID.

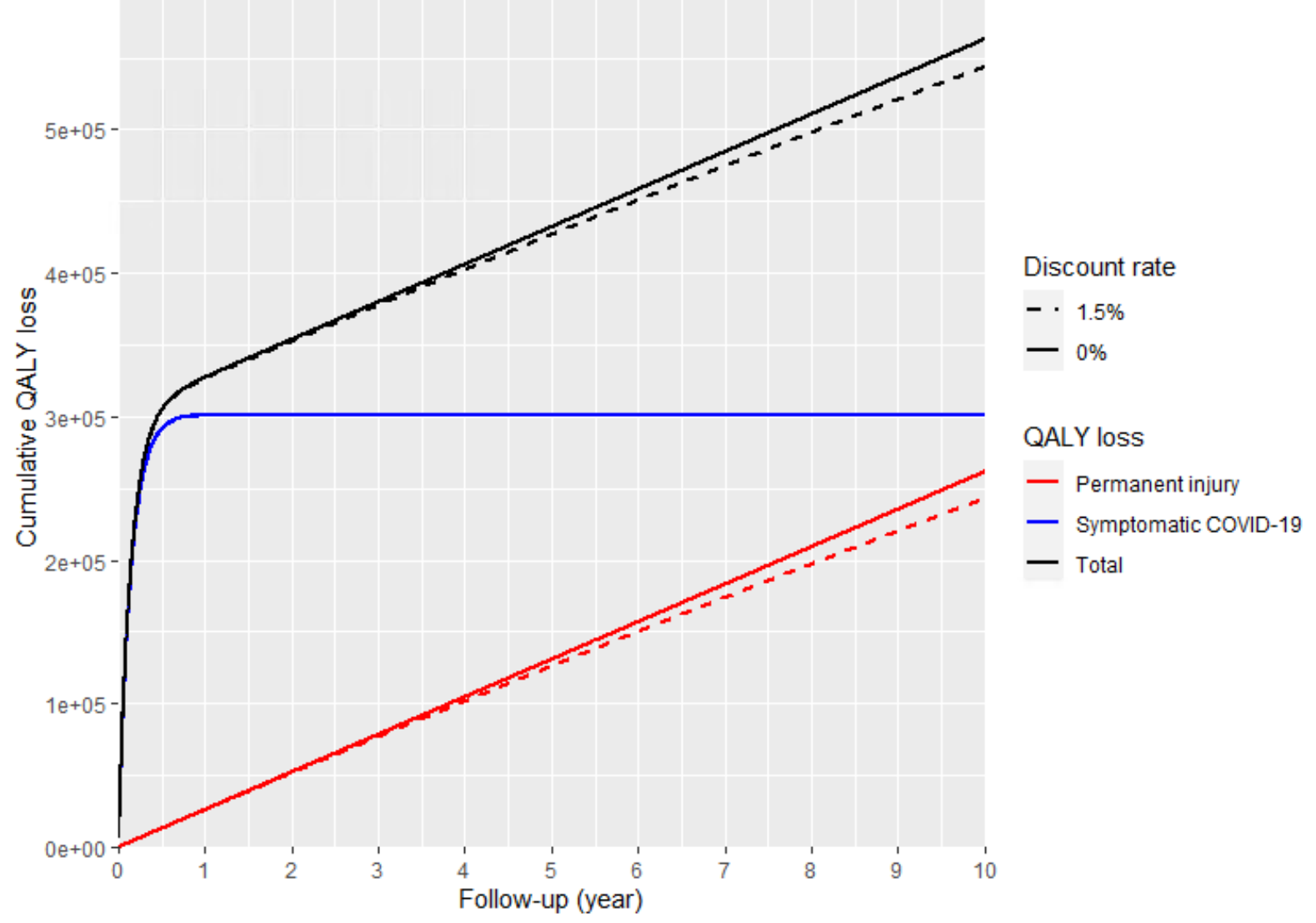

Sensitivity analyses were performed on parameter values in order to assess the robustness of the model over the illustrative 10-year time horizon (Figure 4). Unsurprisingly, discounted QALY loss is sensitive to the time horizon considered. However, as the majority of the QALY loss occurs in the first year, reducing the time horizon from 10 to 1 -year reduced discounted QALY loss by only $44.3 \%$. A 
medRxiv preprint doi: https://doi.org/10.1101/2021.05.18.21252341; this version posted May 20, 2021. The copyright holder for this preprint (which was not certified by peer review) is the author/funder, who has granted medRxiv a license to display the preprint in perpetuity.

It is made available under a CC-BY 4.0 International license .

A model framework for projecting the prevalence and impact of Long-COVID in the UKA model framework for projecting the prevalence and impact of Long-COVID in the UK

reduction or increase in attack rate directly translates into a similar reduction or increase in QALY loss, while the model is less sensitive to parameters to do with QALY loss and prevalence for symptomatic COVID-19 and permanent injury as QALY loss is split between these two conditions. On shorter timeframes, the model would be more sensitive to assumptions around symptomatic COVID-19 prevalence and QOL loss as symptomatic COVID-19 is a larger proportion of total QALY loss at shorter timeframes.

Figure 4: Results of sensitivity analysis on key parameters

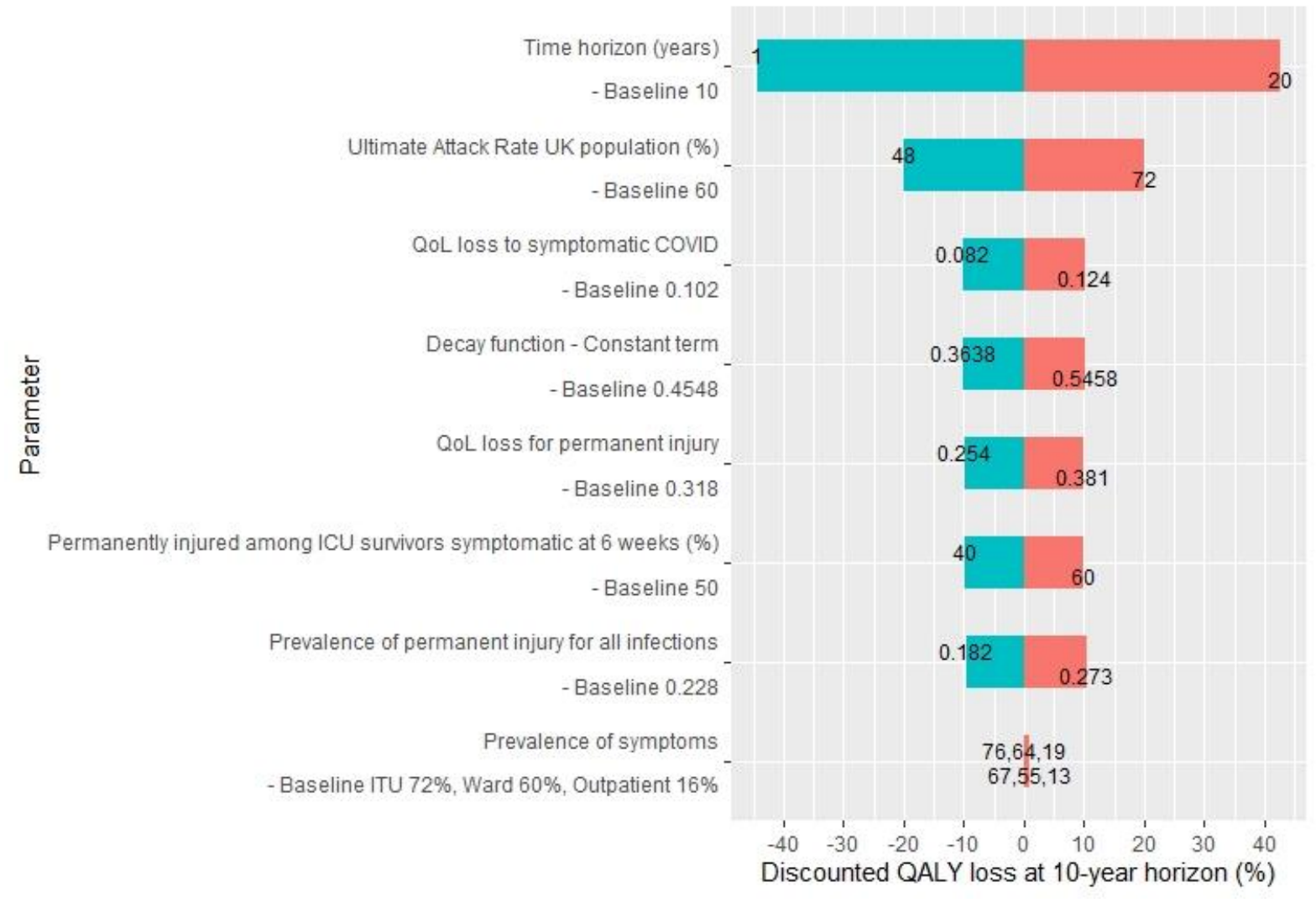


medRxiv preprint doi: https://doi.org/10.1101/2021.05.18.21252341; this version posted May 20, 2021. The copyright holder for this preprint (which was not certified by peer review) is the author/funder, who has granted medRxiv a license to display the preprint in perpetuity.

It is made available under a CC-BY 4.0 International license .

A model framework for projecting the prevalence and impact of Long-COVID in the UKA model framework for projecting the prevalence and impact of Long-COVID in the UK

217 We modelled QALY loss due to COVID-19 symptoms and permanent injury in the UK population. To 218 the best of our knowledge, this is the first such study on a UK population using UK data. Basu and 219 Gandhay modelled the QALY impact of averting a single COVID-19 infection in an American setting(24) and reported QALY loss due to symptomatic (outpatient) COVID-19 of 0.007 ( $95 \% \mathrm{CI}: 0.002-0.011$ ) per COVID-19 infection. This compares to our 0.0075 and 0.0135 for 1 - and 10 -year horizons, respectively. A further 0.002 QALY loss to family members due to symptomatic COVID-19 and 0.048 QALY due to COVID-19 deaths was modelled by Basu and Gandhay, both of which was out of our scope. Basu and Gandhay assumed utility loss for symptomatic outpatients of 0.43 (based on utility of H1N1 patients on the day of index medical visit), compared to our 0.10, based on COVID-19 symptomatic patients on average 48 days post-discharge. Given the longer timeframe of our model (including modelled symptomatic infections), we felt 0.10 is appropriate. In Basu and Gandhay's model, $0.005 \%$ of symptomatic patients recover with permanent kidney injury, while in our model, $0.2 \%$ of all infections resulted in permanent injury.

Various studies have reported widely varying estimates of symptom prevalence (Figure 2). At 12 weeks, the Coronavirus Infection Survey (shown as Population) reports a prevalence of any symptoms of $9.9 \%$ but the Arnold study reports a prevalence of $74 \%$ (shown as Hospitalised). The Arnold study sample includes hospitalised patients only whereas the CIS study is population-based. Even when considering hospitalisation as a risk factor and the different study populations, the prevalence variation appears larger than expected. The Sudre study (shown as App-users) conducted from a COVID app reported a lower symptom prevalence of $2.3 \%$. This might reflect sampling and recording biases as the users were self-selected and responsible for the recording symptoms. The means of eliciting responses in symptom studies can have a significant impact on the estimated prevalence thus making comparison between studies difficult (25-27). Symptom prevalence studies are also complicated by adjusting for background prevalence as well as varying definitions of symptoms.

QALYs can be used to estimate disease burden as it is a measure that reflects both the quantity and quality of life. By integrating the impact of disease on mortality and morbidity into a single index, comparisons between different diseases can be made. For current modelling purposes, it was the most appropriate measure to estimate the prevalence and health impact long-COVID due to its standardised, reproducible and summarised characteristics of HRQoL. However, the effects of COVID19 are not limited to health. There are economic impacts to individuals and the country as well as wellbeing impacts on family members of those symptomatic. Additionally, measures taken to limit the spread of SARS-Cov-2 impact wellbeing and the overall economy (28).

Potential implications

Health and Care Services

Proactive care and tailored intervention support will be required in order to locate and accommodate the needs of these patients in the most appropriate setting. We second the recommendation from Halpin et al. that rehabilitation services should be planned "to manage these symptoms appropriately and maximise the functional return of COVID-19 survivors" (15) There will be a lasting health burden within our society for those who are COVID injured who will require ongoing support. Without adequate planning this may put further pressures on NHS resources.

Prevention is better than cure. We provide these numbers as health economic rationale or a willingness to pay to avoid an accumulation of injury due to COVID-19. This provides further justification for the vaccination programme, which has been shown to provide significant reduction in severe disease outcomes $(29,30)$. Given the socio-economic disparity in the pandemic burden, this 
medRxiv preprint doi: https://doi.org/10.1101/2021.05.18.21252341; this version posted May 20, 2021. The copyright holder for this preprint (which was not certified by peer review) is the author/funder, who has granted medRxiv a license to display the preprint in perpetuity.

It is made available under a CC-BY 4.0 International license.

A model framework for projecting the prevalence and impact of Long-COVID in the UKA model framework for projecting the prevalence and impact of Long-COVID in the UK

may provide justification for spending which seeks to reduce health inequalities such as tailored public health messaging, vaccination delivery, and community access to care. In addition, this provides support for non-pharmaceutical interventions that reduce the transmission of the SARS-Cov-2.

\section{Societal and economic}

For the Symptomatic COVID-19 cohort, return to work may be delayed causing increased claims on statutory sick pay, group employer or individual income protection insurance. For the COVID-injured cohort, some may not return to fully to work. This may cause increased claims on government unemployment and disability benefits. Both cohorts would benefit from flexibility in working arrangements and return to work to better accommodate the individuals' needs and ensure continued employability.

Given the socio-economic disparity in the pandemic burden, there may be a disparity in the economic impact of permanent injury from COVID-19 which warrants further investigation to prevent a generational widening of the health inequality gap. Some in society have been, and are, at increased risk of infection due to their occupation. We agree with the calls for "further research into the role of repeated exposure to SARS-Cov-2 in a healthcare delivery setting and or in the community, and role of the repeated exposures leading to autoimmune mediated responses"(31).

\section{Limitations}

The mechanisms of underlying pathogenesis and resulting symptoms of COVID-19 is not yet fully understood. Although NICE have published a working definition, this may be subject to change. This model estimates a disease that is evolving and as such, its ability to predict long-term outcomes will be limited. There is uncertainly around some of the parameters being used in the model and a number of assumptions had to be made. Survival rates of ward and ITU care were based on 2020 data and could since have improved as improvements are being made in care for COVID-19 patients. Improved knowledge on treatment for COVID-19 in wards and ITUs could also reduce the proportion of permanently injured amongst survivors.

The quality of the symptom prevalence data used could be improved by standardising measurement and recording of symptoms. Currently data is being gathered using different types of questionnaire in different mediums e.g., Halpin (2020) developed their own COVID-19 rehabilitation telephone screening tool, Arnold (2020) used the SF-36 questionnaire and Sudre (2020) used a self-reporting questionnaire via an app. Standardised and validated questionnaires and tools exist and are used to record patient reported outcomes (PROs). These include the St George's respiratory questionnaire and the MRC dyspnoea scale $(32,33)$. However, these are often disease-specific and may not be appropriate for use in long-COVID patients. In addition, HRQoL questionnaires like SF-36 maybe too general and may not capture all effects resulting from the multiple possible symptoms of COVID-19.

The Coronavirus Infection Survey study was used to inform the prevalence of ongoing symptoms from diagnosis. It was the study with the largest sample and it also reflected the general population prevalence due to the sampling methods used. Currently, we know the prevalence of ongoing symptoms up to 12-weeks while the pandemic has lasted for more than 1-year so this is a relatively short timeframe evidence base. As the survey continues to collect more data, the prevalence figures could be updated to better reflect long-term outcomes.

Our calculation of infections that result in long-COVID uses fatigue as the most common symptom post-discharge (15). This symptom was used as it was the most commonly reported in the symptom prevalence studies. However, fatigue is also a commonly reported symptom in the general population and prevalence varies. One review of fatigue as a symptom in 1992 found prevalence estimates in the 
medRxiv preprint doi: https://doi.org/10.1101/2021.05.18.21252341; this version posted May 20, 2021. The copyright holder for this preprint (which was not certified by peer review) is the author/funder, who has granted medRxiv a license to display the preprint in perpetuity.

It is made available under a CC-BY 4.0 International license .

A model framework for projecting the prevalence and impact of Long-COVID in the UKA model framework for projecting the prevalence and impact of Long-COVID in the UK

general population ranging from $4 \%$ to $45 \%$ (26). Therefore, when a patient reports 'fatigue' it is not known if the symptom is due to long-COVID or other factors. In addition, the interviewer asks the interviewee to reference the time of interview and to a pre-COVID state which may result in recall bias.

One of the assumptions of the model is that the average lost QALY rate for symptomatic patients in shorter durations is similar to the Long-COVID lost QALY rate. This will affect how well the lost QALY rate estimated by the model reflects the actual HRQoL of long-COVID. Again, as more data is collected on HRQoL in patients with persistent symptoms, these limitations can be reconciled.

\section{Conclusion}

This article describes a model for estimating the health impact of COVID-19 symptoms, including longCOVID and permanent injury from COVID-19. Quality adjusted life-years lost are used to present a standardised measure of the impacts and uses the HM Treasury to quantify the impact in monetary terms. The model framework is presented such that it can be updated with information as more reliable data accumulates. Based on the current parameterisation, 557,754 QALYs would be lost over 10-years, 286,454 to permanent injury as a result of COVID-19 and 271,300 from symptoms of COVID19 across all timescales. An estimated 90,142 people could be left living with significant impairments as a result of injury from COVID-19.

This model framework highlights just some of the factors that will influence the impact of the LongCOVID burden in our society, our limited understanding of the condition to date, and the limited information available. There is great uncertainty in the prevalence of symptoms over time as a result of lack of standardisation in methods used to measure it. Standardised patient report outcomes instruments need to be used, and there may be a need to develop and validate COVID-19 specific symptom measures.

\section{Acknowledgements}

Many people have supported this work, including:

- Steve Bale, Senior Actuary, Munich Re

- Scott Reid, Global Protection Pricing \& Product Development Actuary, Zurich Insurance

- Matt Gurden, Actuarial Director, Government Actuary's Department

- Louisa Rutherford, Medical writer, Crystallise

- Holly Gould, Researcher, Crystallise

- Hannah Rice, Researcher, Crystallise

- Walter Rodney Ngumo, Researcher, Crystallise

- Nicola Clarke, Researcher, Crystallise

- Christian Todaro, Researcher, Crystallise

- Colin Dutkiewicz, Global Head of Life, Aon Reinsurance Solutions

\section{References}

1. Huang C, Wang Y, Li X, Ren L, Zhao J, Hu Y, et al. Clinical features of patients infected with 2019 novel coronavirus in Wuhan, China. Lancet. 2020;395(10223):497-506.

2. World Health Organization. Coronavirus disease (COVID-19) pandemic [Internet]. 2021 [cited 2021 Apr 24]. Available from: https://www.who.int/emergencies/diseases/novelcoronavirus-2019 
medRxiv preprint doi: https://doi.org/10.1101/2021.05.18.21252341; this version posted May 20, 2021. The copyright holder for this preprint (which was not certified by peer review) is the author/funder, who has granted medRxiv a license to display the preprint in perpetuity.

It is made available under a CC-BY 4.0 International license .

A model framework for projecting the prevalence and impact of Long-COVID in the UKA model

framework for projecting the prevalence and impact of Long-COVID in the UK

3. GOV.UK Coronavirus (COVID-19) in the UK [Internet]. 2020 [cited 2020 Dec 22]. Available from: https://coronavirus.data.gov.uk/

4. NICE, SIGN, RCGP. COVID-19 rapid guideline: managing the long-term effects of COVID-19. London, Edinburgh; 2020.

5. Arnold DT, Hamilton FW, Milne A, Morley AJ, Viner J, Attwood M, et al. Patient outcomes after hospitalisation with COVID-19 and implications for follow-up: results from a prospective UK cohort. Thorax [Internet]. 2020 Dec 3;thoraxjnl-2020-216086. Available from: https://thorax.bmj.com/lookup/doi/10.1136/thoraxjnl-2020-216086

6. Fraser E. Long term respiratory complications of covid-19. BMJ [Internet]. 2020 Aug 3;m3001. Available from: https://www.bmj.com/lookup/doi/10.1136/bmj.m3001

7. Kamdar BB, Suri R, Suchyta MR, Digrande KF, Sherwood KD, Colantuoni E, et al. Return to work after critical illness: a systematic review and meta-analysis. Thorax [Internet]. 2020 Jan;75(1):17-27. Available from: https://thorax.bmj.com/lookup/doi/10.1136/thoraxjnl2019-213803

8. Zhou F, Yu T, Du R, Fan G, Liu Y, Liu Z, et al. Clinical course and risk factors for mortality of adult inpatients with COVID-19 in Wuhan, China: a retrospective cohort study. Lancet [Internet]. 2020;6736(20):1-9. Available from: http://dx.doi.org/10.1016/s01406736(20)30566-3

9. Office for National Statistics. The prevalence of long COVID symptoms and COVID-19 complications [Internet]. 2020 [cited 2021 Jan 19]. Available from:

https://www.ons.gov.uk/news/statementsandletters/theprevalenceoflongcovidsymptomsan dcovid19complications

10. Herridge MS, Moss M, Hough CL, Hopkins RO, Rice TW, Bienvenu OJ, et al. Recovery and outcomes after the acute respiratory distress syndrome (ARDS) in patients and their family caregivers. Intensive Care Med [Internet]. 2016 May 30;42(5):725-38. Available from: http://link.springer.com/10.1007/s00134-016-4321-8

11. Herridge MS, Tansey CM, Matté A, Tomlinson G, Diaz-Granados N, Cooper A, et al. Functional Disability 5 Years after Acute Respiratory Distress Syndrome. N Engl J Med [Internet]. 2011 Apr 7;364(14):1293-304. Available from: http://www.nejm.org/doi/abs/10.1056/NEJMoa1011802

12. Ahmed H, Patel K, Greenwood D, Halpin S, Lewthwaite P, Salawu A, et al. Long-term clinical outcomes in survivors of severe acute respiratory syndrome and Middle East respiratory syndrome coronavirus outbreaks after hospitalisation or ICU admission: A systematic review and meta-analysis. J Rehabil Med [Internet]. 2020; Available from:

https://www.medicaljournals.se/jrm/content/abstract/10.2340/16501977-2694

13. McDonald S, Martin C, Bale S, Luteijn M, Sarkar R. Construction of a demand and capacity model for intensive care and hospital ward beds, and mortality from COVID-19. MedRxiv [Internet]. 2021; Available from: https://www.medrxiv.org/content/10.1101/2021.01.06.21249341v1

14. Briggs AH, Goldstein DA, Kirwin E, Meacock R, Pandya A, Vanness DJ, et al. Estimating (quality-adjusted) life-year losses associated with deaths: With application to COVID-19. Health Econ [Internet]. 2021 Mar 24;30(3):699-707. Available from: https://onlinelibrary.wiley.com/doi/10.1002/hec.4208

15. Halpin SJ, Mclvor C, Whyatt G, Adams A, Harvey O, McLean L, et al. Postdischarge symptoms and rehabilitation needs in survivors of COVID-19 infection: A cross-sectional evaluation. J Med Virol [Internet]. 2021 Feb 17;93(2):1013-22. Available from: https://onlinelibrary.wiley.com/doi/10.1002/jmv.26368

16. Sudre C, Murray B, Varsavsky T, Graham M, Penfold R, Bowyer R, et al. Attributes and predictors of Long-COVID: analysis of COVID cases and their symptoms 2 collected by the Covid Symptoms Study App. MedRxiv [Internet]. 2020; Available from: https://www.medrxiv.org/content/10.1101/2020.10.19.20214494v2 
medRxiv preprint doi: https://doi.org/10.1101/2021.05.18.21252341; this version posted May 20, 2021. The copyright holder for this preprint (which was not certified by peer review) is the author/funder, who has granted medRxiv a license to display the preprint in perpetuity.

It is made available under a CC-BY 4.0 International license .

A model framework for projecting the prevalence and impact of Long-COVID in the UKA model framework for projecting the prevalence and impact of Long-COVID in the UK

17. Docherty AB, Harrison EM, Green CA, Hardwick HE, Pius R, Norman L, et al. Features of 20 133 UK patients in hospital with covid-19 using the ISARIC WHO Clinical Characterisation Protocol: Prospective observational cohort study. BMJ. 2020;369(March):1-12.

18. ICNARC. ICNARC report on COVID-19 in critical care: England, Wales and Northern Ireland 24 December 2020 [Internet]. 2020. Available from: https://www.icnarc.org/Our-

Audit/Audits/Cmp/Reports

19. COVID-19 Daily Deaths [Internet]. england.nhs.uk. [cited 2020 Oct 21]. Available from: https://www.england.nhs.uk/statistics/statistical-work-areas/covid-19-daily-deaths/

20. ONS. Coronavirus (COVID-19) Infection Survey: antibody data for the UK, January 2021 [Internet]. 2021 [cited 2021 Jan 22]. Available from:

https://www.ons.gov.uk/peoplepopulationandcommunity/healthandsocialcare/conditionsan ddiseases/articles/coronaviruscovid19infectionsinthecommunityinengland/antibodydatafort heukjanuary2021

21. Marti J, Hall P, Hamilton P, Lamb S, McCabe C, Lall R, et al. One-year resource utilisation, costs and quality of life in patients with acute respiratory distress syndrome (ARDS):

Secondary analysis of a randomised controlled trial. J Intensive Care [Internet]. 2016;4(1):111. Available from: http://dx.doi.org/10.1186/s40560-016-0178-8

22. Janssen MF, Szende A, Cabases J, Ramos-Goñi JM, Vilagut G, König HH. Population norms for the EQ-5D-3L: a cross-country analysis of population surveys for 20 countries. Eur J Heal Econ [Internet]. 2019 Mar 14;20(2):205-16. Available from: http://link.springer.com/10.1007/s10198-018-0955-5

23. HM Treasury. THE GREEN BOOK CENTRAL GOVERNMENT GUIDANCE ON APPRAISAL AND EVALUATION. London; 2020.

24. Basu A, Gandhay VJ. Quality-Adjusted Life-Year Losses Averted With Every COVID-19 Infection Prevented in the United States. Value Heal [Internet]. 2021 Mar; Available from:

https://linkinghub.elsevier.com/retrieve/pii/S1098301521000346

25. Ophuis RH, Olij BF, Polinder S, Haagsma JA. Prevalence of post-traumatic stress disorder, acute stress disorder and depression following violence related injury treated at the emergency department: a systematic review. BMC Psychiatry [Internet]. 2018 Dec 25;18(1):311. Available from:

https://bmcpsychiatry.biomedcentral.com/articles/10.1186/s12888-018-1890-9

26. Carlson KF, Kehle SM, Meis LA, Greer N, MacDonald R, Rutks I, et al. Prevalence, Assessment, and Treatment of Mild Traumatic Brain Injury and Posttraumatic Stress Disorder. J Head Trauma Rehabil [Internet]. 2011;26(2):103-15. Available from: http://journals.Iww.com/00001199-201103000-00001

27. Lewis $G$, Wessely $S$. The epidemiology of fatigue: more questions than answers. J Epidemiol Community Heal [Internet]. 1992 Apr 1;46(2):92-7. Available from:

https://jech.bmj.com/lookup/doi/10.1136/jech.46.2.92

28. Zala D, Mosweu I, Critchlow S, Romeo R, McCrone P. Costing the COVID-19 Pandemic: An Exploratory Economic Evaluation of Hypothetical Suppression Policy in the United Kingdom. Value Heal [Internet]. 2020 Nov;23(11):1432-7. Available from: https://linkinghub.elsevier.com/retrieve/pii/S1098301520322075

29. Ramasamy MN, Minassian AM, Ewer KJ, Flaxman AL, Folegatti PM, Owens DR, et al. Safety and immunogenicity of ChAdOx1 nCoV-19 vaccine administered in a prime-boost regimen in young and old adults (COVO02): a single-blind, randomised, controlled, phase $2 / 3$ trial. Lancet [Internet]. 2020 Dec;396(10267):1979-93. Available from: https://linkinghub.elsevier.com/retrieve/pii/S0140673620324661

30. Baden LR, El Sahly HM, Essink B, Kotloff K, Frey S, Novak R, et al. Efficacy and Safety of the mRNA-1273 SARS-CoV-2 Vaccine. N Engl J Med [Internet]. 2021 Feb 4;384(5):403-16.

Available from: http://www.nejm.org/doi/10.1056/NEJMoa2035389

31. Alwan NA, Attree E, Blair JM, Bogaert D, Bowen M-A, Boyle J, et al. From doctors as patients: 
medRxiv preprint doi: https://doi.org/10.1101/2021.05.18.21252341; this version posted May 20, 2021. The copyright holder for this preprint (which was not certified by peer review) is the author/funder, who has granted medRxiv a license to display the preprint in perpetuity.

It is made available under a CC-BY 4.0 International license.

A model framework for projecting the prevalence and impact of Long-COVID in the UKA model framework for projecting the prevalence and impact of Long-COVID in the UK

a manifesto for tackling persisting symptoms of covid-19. BMJ [Internet]. 2020 Sep 15;m3565. Available from: https://www.bmj.com/lookup/doi/10.1136/bmj.m3565

32. Littlejohns $\mathrm{P}$, Ebrahim $\mathrm{S}$, Anderson R. Prevalence and diagnosis of chronic respiratory symptoms in adults. Br Med J [Internet]. 1989;298(6687):1556-60. Available from: https://rsm.idm.oclc.org/login?url=https://www.rsm.ac.uk?url=https://dialog.proquest.com/ professional/docview/701275003?accountid=138535

33. Mahler DA, Wells CK. Evaluation of Clinical Methods for Rating Dyspnea. Chest [Internet]. 1988 Mar;93(3):580-6. Available from: 